\title{
Effect of drying method and storage conditions on the essential oil yield and composition of Eugenia uniflora L. leaves
}

\section{Efecto del método de secado y condiciones de almacenamiento en el rendimiento y composición de aceite esencial en hojas de Eugenia uniflora L.}
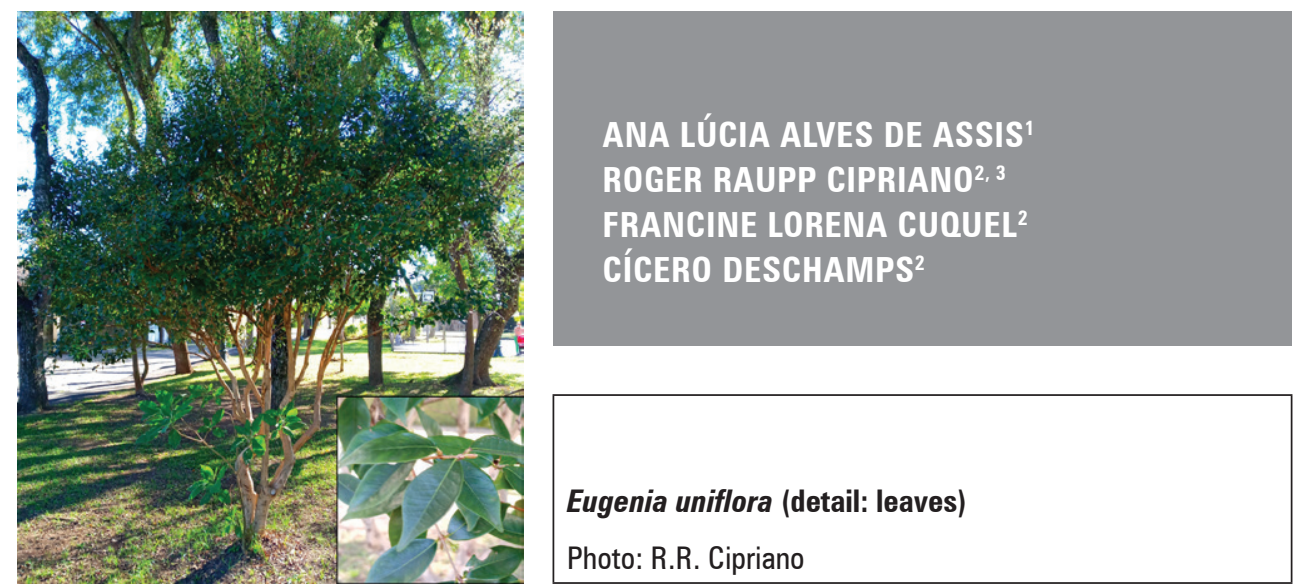

\section{ABSTRACT}

The essential oil produced by Eugenia uniflora leaves is intensively used by the cosmetic, pharmaceutic and perfumery industries, mainly because its antioxidant effect and antimicrobial and antihelmintic ativities. Drying and storage of aromatic plant leaves can affect yield and quality of essential oils. This study aimed to evaluate the effect of drying method and storage conditions on the essential oil yield and composition in Eugenia uniflora leaves. The essential oil was extracted from dried leaves at ambient temperature and at $45^{\circ} \mathrm{C}$ for six drying periods (0, 6, 24, 48, 72 and 96 hours). The essential oil yield was also analyzed after 0, 60, 120, and 180 days of storage in three types of packaging. The oil was extracted with hydrodistillation, and the composition was determined with gas chromatography-mass spectrometry. The results showed that drying leaves at ambient temperature and $45^{\circ} \mathrm{C}$ for 48 and 24 hours, respectively, increased the essential oil yield. At $45^{\circ} \mathrm{C}$, the monoterpene and sesquiterpene compounds increased, with curzerene+viridiflorene identified as the major compounds. The packaging did not affect the essential oil yield but increasing the storage period decreased it.

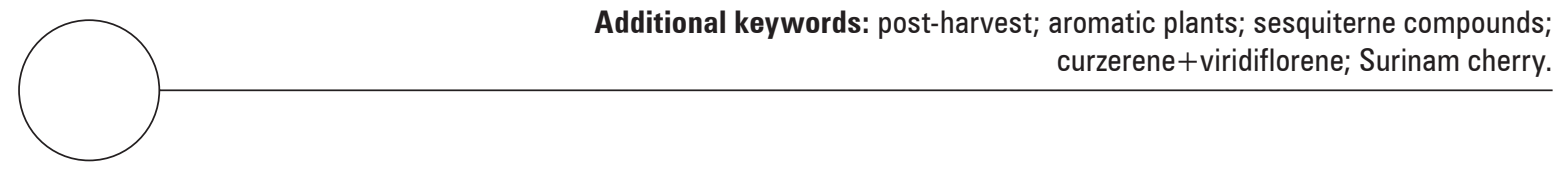

Pontifícia Universidade Católica do Paraná, Curitiba (Brazil). ORCID Assis, A.L.A.: 0000-0003-1936-7286

2 Universidade Federal do Paraná, Setor de Ciências Agrárias, Curitiba (Brazil). ORCID Cipriano, R.R.: 0000-0002-3896-9074; ORCID Cuquel, F.L.: 0000-0002-3026-2058; ORCID Deschamps, C.: 0000-0003-0786-0532

3 Corresponding author. rogerraupp@gmail.com 


\section{RESUMEN}

El aceite esencial producido por las hojas de Eugenia uniflora es utilizado intensamente por las industrias cosmética, farmacéutica y de perfumería principalmente debido a su efecto antioxidante y sus actividades antimicrobianas y antihelmínticas. El secado y el almacenamiento de las hojas de plantas aromáticas pueden afectar el rendimiento y la calidad de su aceite esencial. Este estudio tuvo como objetivo evaluar el efecto del método de secado y las condiciones de almacenamiento sobre el rendimiento y la composición del aceite esencial en las hojas de Eugenia uniflora. El aceite esencial se extrajo de hojas secas a temperatura ambiente y a $45^{\circ} \mathrm{C}$ durante seis períodos de secado $(0,6$, 24, 48, 72 y 96 horas). El rendimiento del aceite esencial también se analizó después de 0, 60, 120 y 180 días de almacenamiento en tres tipos de envases. El aceite se extrajo por hidrodestilación y la composición se determinó por cromatografía de gases - espectrometría de masas. Los resultados mostraron que el secado de las hojas a temperatura ambiente y $45^{\circ} \mathrm{C}$ durante 48 y 24 horas, respectivamente, aumentó el rendimiento del aceite esencial. A $45^{\circ} \mathrm{C}$, los compuestos de monoterpeno y sesquiterpeno aumentaron, con curzereno + viridifloreno identificado como los compuestos principales. Los tipos de paquetes no afectaron el rendimiento del aceite esencial, pero el aumento del período de almacenamiento lo disminuyó.

Palabras clave adicionales: poscosecha; plantas aromáticas; compuestos serquiterpenos; curzereno+viridifloreno; Pitanga.

Received for publication: 06-06-2019 Accepted for publication: 11-06-2020

\section{INTRODUCTION}

Surinam cherry, Brazilian cherry or Cayenne cherry (Eugenia uniflora L.), belongs to the Myrtaceae family and is a native plant species of the tropical east coast of South America, with dispersion from Suriname to southern Brazil (Lorenzi and Matos, 2008). The essential oil produced in the leaves is suggested as an important raw material for the cosmetic, pharmaceutical and perfumery industries because of its antioxidant effect and antimicrobial and antihelmintic ativities (Amorim et al., 2009; Gallucci et al., 2010; Victoria et al., 2012; Rodrigues et al., 2013; Santos et al., 2018).

According to Melo et al. (2007), the major constituents in Surinam cherry essential oil are furanodiene and its rearrangement products, furanoelemene (or curzerene, $50.2 \%)$, $\beta$-elemene $(5.9 \%)$ and $\alpha$-cadinol (4.7\%). However, the essential oil composition of this species is reported as greatly varied in the literature, associated with phenotypic characteristics (Costa et al., 2010) and edaphoclimatic conditions (Costa et al., 2009; Rodrigues et al., 2013; Santos et al., 2018; Silva et al., 2018).

Because of the high variability found in the essential oil of Surinam cherries during the different seasons of the year and also because it is a semi-deciduous species, the development of drying techniques allows
Surinam cherry leaves to be stored and marketed throughout the year. The drying of aromatic plants can be natural, which is generally carried out under shade and at ambient temperature, or done with artificial driers, with or without ventilation (Rocha et al., 2011). The drying process preserves a plant's active components by reducing the oxidation process and microbial growth (Harbourne et al., 2009; Voung et al., 2015).

The drying method can also affect the essential oil yield of aromatic plants, as demonstrated by Amaral et al. $(2018,2019)$ in native Brazilian species of the Myrtaceae and Asteraceae families. Choosing the drying method is particularly important for aromatic plants since it can affect essential oil yield and composition according to the plant species and the secretory structure where the oil is accumulated (Rahimmalek and Goli, 2013).

Some plant species rely on the drying method to reduce moisture and break the secretory structures containing the essential oil. Studies have indicated that high drying temperatures facilitate lysigenous cell disruption within the parenchyma, resulting in increased essential oil yield (Hannaa et al., 2012; Pirbalouti et al., 2013). 
In addition to the drying process, storage conditions also affect essential oil yield (Lisboa et al., 2018). However, studies on these procedures in Eugenia uniflora are scarce. The optimum storage conditions for Surinam cherry leaves is needed to improve essential oil production.

This study aimed to characterize the essential oil yield and composition of Eugenia uniflora leaves dried at different temperatures for different periods of time and after storage in different types of package materials.

\section{MATERIALS AND METHODS}

The plant material was collected in Parana State

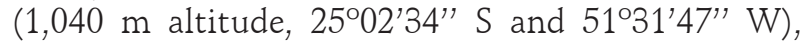
Brazil, in June (2012).

The leaves of ten Surinam cherry trees, with dark red fruits, were selected for diameter at breast height, ranging from 20 to $32 \mathrm{~cm}$. Exsiccates of fresh branches were deposited in the "Integrated Spiritist College Herbarium", Curitiba, Parana (register HFIE 9.127).

\section{Drying experiment}

The drying experiment was carried out in a completely randomised design, comparing the effect of temperature (room temperature of $22^{\circ} \mathrm{C}$ and dryer temperature of $45^{\circ} \mathrm{C}$ ) for $6,24,48,72$ and $96 \mathrm{~h}$, as compared to non-dried leaves, with three replications The fresh leaf samples were homogenised and separated into sub-samples (approximately $4 \mathrm{~kg}$ ) for each replication. The leaves were air-dried at room temperature and relative humidity (69\%) in the absence of direct sunlight incidence. The controlled temperature drying was done at $45^{\circ} \mathrm{C}$ with forced ventilation (Nova Ética ${ }^{\circledR}$ ).

The essential oil was isolated with hydrodistillation in a Clevenger graduated apparatus using $100 \mathrm{~g}$ of leaves in $1 \mathrm{~L}$ of distilled water, for $4 \mathrm{~h}$, according to the Brazilian Pharmacopoeia recommendations (ANVISA, 2020). The essential oil components were subsequently identified and quantified with gas chromatography-mass spectrometry $\left(60-240^{\circ} \mathrm{C}, 3^{\circ} \mathrm{C} \mathrm{min}{ }^{-1}\right.$ ramp) in an Agilent 7890A device with a DB-5 (30 m $\times 0.25 \mathrm{~mm} \times 0.25 \mu \mathrm{m}$ ) capillary column, operating in a 1:5 flow divider mode. The injector and detector temperatures were 250 and $280^{\circ} \mathrm{C}$, respectively.
Helium was used as the carrier gas at a flow of $1 \mathrm{~m}$ $\mathrm{min}^{-1}$. The essential oil was diluted in hexane to a concentration of $1 \%$, and an aliquot of this solution $(1 \mu \mathrm{L})$ of each sample was injected. The mass spectra were obtained with electron ionisation at $70 \mathrm{eV}$ with an acquisition rate of $3.15 \mathrm{scans} / \mathrm{s}$, in the range of 40 to $500 \mathrm{Da}$. The essential oil components were identified by comparing the retention indices of the components with those of a homologous series of n-alkanes (C11-C24) injected into the same column and were calculated according to the Van den Dool and Kratz (1963) equation. The mass spectra were compared with data from the Wiley/NBS Spectrotech, and the linear retention indices were verified according to the literature data (Adams, 2017).

The essential oil yield was determined by calculating the density and the corrected values for dried mass (DM), and the subsample moisture percentage was determined with $10 \mathrm{~g}$ of leaves perr repetition.

\section{Storage experiment}

To evaluate the influence of storage type and time on the yield of the essential oil, $200 \mathrm{~g}$ of fresh leaves were dried to $11 \%$ moisture with the Ecodryer method with a controlled air speed and drying temperature $\left(70^{\circ} \mathrm{C}\right.$ on the leaves). The experiment design was completely randomized in a $3 \times 4$ factorial, comparing the package types and four storage periods (60, $120,180 \mathrm{~d}$ and with no storage), with five replications. The package types included polyethylene raffia bags $\left(70 \mathrm{~g} \mathrm{~m}^{-2}\right)$, polyethylene transparent bags (10 $\mu \mathrm{m})$ and double kraft bags $\left(200 \mathrm{~g} \mathrm{~m}^{-2}\right)$, and wrapped in a polyethylene transparent bags $(10 \mu \mathrm{m})$. The packaged leaves were kept under a wooden "pallet" measuring $1 \times 1.2 \mathrm{~m}$, simulating the storage system used in the medicinal and aromatic plant industries.

Prior to storage, 15 essential oil extractions were performed on fresh leaves (controls) containing 53\% moisture. A further 15 essential oil extractions were performed on dried leaves, containing $11 \%$ moisture. These extractions provided a statistical comparison related to the storage treatments.

Essential oil yield was determined by calculating the density and the corrected values for dried mass (DM). The subsample moisture percentage was determined with $10 \mathrm{~g}$ of leaves per repetition.

The treatment variances were tested for homogeneity with Bartlett's test. The averages were compared 
with Tukey's test at $5 \%$ probability, using the statistical program ASSISTAT version 7.7 (Silva and Azevedo, 2016).

\section{RESULTS AND DISCUSSION}

\section{Drying experiment}

\section{Essential oil yield}

The drying of Surinam cherry leaves resulted in a significant increase in essential oil yield. The highest average was obtained when the leaves were dried at $45^{\circ} \mathrm{C}$ for $24 \mathrm{~h}\left(3.7 \mu \mathrm{L} \mathrm{g}^{-1} \mathrm{DM}\right)$ and at ambient temperature for $48 \mathrm{~h}\left(3.5 \mu \mathrm{L} \mathrm{g}^{-1} \mathrm{DM}\right)$ (Tab. 1).

\section{Table 1. Average essential oil yield ( $\left.\mu \mathrm{L} \mathrm{g}^{-1} \mathrm{DM}\right)$ of Suri- nam cherry leaves prepared by different drying treatments.}

\begin{tabular}{|l|c|c|}
\hline \multirow{2}{*}{ Time (h) } & \multicolumn{2}{|c|}{ Drying temperature } \\
\cline { 2 - 3 } & Ambient $\left(22^{\circ} \mathrm{C}\right)$ & $45^{\circ} \mathrm{C}$ \\
\hline 0 & $2.5 \mathrm{aB}$ & $2.0 \mathrm{bB}$ \\
\hline 6 & $2.2 \mathrm{aBC}$ & $2.0 \mathrm{aB}$ \\
\hline 24 & $2.1 \mathrm{bBC}$ & $3.7 \mathrm{aA}$ \\
\hline 48 & $3.5 \mathrm{aA}$ & $1.8 \mathrm{bB}$ \\
\hline 72 & $1.6 \mathrm{aC}$ & $2.0 \mathrm{aB}$ \\
\hline 96 & $1.7 \mathrm{aC}$ & $1.5 \mathrm{aB}$ \\
\hline CV (\%) & \multicolumn{2}{|c|}{11.3} \\
\hline
\end{tabular}

$\mathrm{CV}(\%)=$ coefficient of variation; $\mathrm{DM}=$ dried mass; Averages with the same lowercase letters in the rows and capital letters in the columns are not significantly different according to Tukey's test $(P<0.05)$.

Previous results for other aromatic plant species are similar to this study, where a high essential oil yield was found under specific drying temperatures. In Lippia citriodora, the highest essential oil yield was obtained at $30^{\circ} \mathrm{C}$, with a significant decrease at higher temperatures (Shahhoseini et al., 2013). Pirbalouti et al. (2013), who compared different drying methods for Satureja bachtiarica, found the highest oil yields at $45^{\circ} \mathrm{C}$ for $48 \mathrm{~h}$.

The changes in essential oil yield of aromatic plants after drying can be related to the anatomy of the storage structures. According to Fiuza et al. (2008), the essential oil in Eugenia uniflora leaves is located in the palisade parenchyma, within secretory cavities or oil channels. Increasing the drying temperature and consequent water removal from the cells may contribute to degradation of the leaf tissue and release of the essential oil from the secretory cavities of the palisade parenchyma.

However, in other species, especially those from the Lamiaceae family, which mainly accumulate essential oil in glandular trichomes, an increase in drying temperature may reduce the essential oil yield, as observed in Thymus vulgaris (Sározi et al., 2013), Melissa officinalis (Argyropoulos and Müller, 2014) and Hyssopus officinalis (Venditti et al., 2015). In these species, an increase in temperature during the drying process drastically reduces the yield of essential oils because of the high volatization (Abdelmageed et al., 2011).

The volatization process can also decrease the essential oil yield when subjected to prolonged drying times (Sellami et al., 2011; Rahimmalek and Goli, 2013). In this experiment, drying over $48 \mathrm{~h}$ at room temperature or $24 \mathrm{~h}$ at $45^{\circ} \mathrm{C}$ reduced the essential oil yield at similar levels from those obtained with fresh leaves. According to Argyropoulos and Müller (2014), the decrease in the essential oil yield may be associated with moisture losses in plant material during the drying process. Prolonged drying times in species such as Eugenia uniflora have a high moisture loss, with a consequent increase in the rupture of the storage structures and volatilization reducing essential oil yield.

\section{Essential oil composition}

The essential oil samples of leaves dried at room temperature and $45^{\circ} \mathrm{C}$ had 12 compounds that were identified, with averages of 60 and $67.1 \%$ identification, respectively. Sesquiterpenes were the most representative compounds in the analyzed samples (Tab. 2), which agrees with other studies carried out on the species (Gallucci et al., 2010; Rodrigues et al., 2013). According to Stefanello et al. (2011), this class of compounds is responsible for the biological action of essential oils from species of the Myrtaceae family.

The major constituents found in the essential oil of the Surinam cherry leaves were viridiflorene+curzerene $\left(15.5 \%\right.$ at $19^{\circ} \mathrm{C}$ and $14.6 \%$ at $\left.45^{\circ} \mathrm{C}\right)$, globulol $(7.7 \%$ at $19^{\circ} \mathrm{C}$ and $8.8 \%$ at $\left.45^{\circ} \mathrm{C}\right)$ and $\alpha$-cadinol $\left(7.4 \%\right.$ at $19^{\circ} \mathrm{C}$ and $8.6 \%$ at $45^{\circ} \mathrm{C}$ ) (Tab. 2). According to Pripdeevech and Chukeatirote (2010), these constituents have antifungal and antioxidant properties. 
Table 2. Average essential oil composition (\%) of Surinam cherry leaves with different drying temperatures.

\begin{tabular}{|c|c|c|c|c|}
\hline \multirow{2}{*}{ Compound* } & \multirow{2}{*}{ Rle } & \multirow{2}{*}{ Rit } & \multicolumn{2}{|c|}{ Drying temperature } \\
\hline & & & Ambient $\left(22^{\circ} \mathrm{C}\right)$ & $45^{\circ} \mathrm{C}$ \\
\hline (E)- $\beta$-Ocimene & 1052 & 1044 & - & 2.1 \\
\hline$\gamma$-Elemene & 1433 & 1434 & 1.4 & 1.8 \\
\hline Allo-Aromadendrene & 1460 & 1458 & 1.1 & 1.3 \\
\hline Germacrene D & 1481 & 1484 & 3.7 & 4.9 \\
\hline Viridiflorene + Curzerene & 1498 & $1496 / 1499$ & 15.5 & 14.6 \\
\hline Germacrene B & 1557 & 1559 & 3.9 & 5.9 \\
\hline Palustrol + ni & 1569 & 1567 & 2.4 & 2.1 \\
\hline Globulol & 1588 & 1590 & 7.7 & 8.8 \\
\hline Viridiflorol + Cubeban-11-ol & 1595 & 1592/ 1595 & 5.8 & 5.0 \\
\hline Epi- $\alpha$-Muurolol & 1647 & 1640 & 5.3 & 7.5 \\
\hline$\alpha$-Cadinol & 1661 & 1652 & 7.4 & 8.6 \\
\hline Germacrone + ni & 1694 & 1693 & 5.8 & 4.5 \\
\hline \multicolumn{3}{|l|}{ Monoterpene hydrocarbons } & - & 2.1 \\
\hline \multicolumn{3}{|l|}{ Sesquiterpene hydrocarbons } & 10.1 & 13.9 \\
\hline \multicolumn{3}{|l|}{ Oxygenated sesquiterpenes } & 49.9 & 51.1 \\
\hline \multicolumn{3}{|l|}{ Total identified } & 60.0 & 67.1 \\
\hline
\end{tabular}

$\mathrm{ni}=$ not identified; Rle $=$ retention index calculated from the compounds retention times with that of a homologous n-alkane series using a DB- 5 column; Rlt $=$ retention index Adams (2017); * Identified compounds with an average content above $1 \%$.

The characteristic scent of Eugenia uniflora essential oil used in the cosmetics industry is associated with nine compounds (globulol, a-cadinol, viridiflorol, espatulenol, $\beta$-elemene, $\gamma$-elemene, germacrone, furanodiene+curzerene, atractylone). The presence of furanodiene+curzerene, $\gamma$-elemene and germacrone provides a spicy and woody aroma similar to the fruit, as verified through an olfactory comparative analysis (Melo et al., 2007).

The analysis of the Surinam cherry essential oil composition in this study indicated that the genetic material presented six olfactory components (curzerene, globulol, a-cadinol, germacrene, viridiflorol and $\gamma$-elemene), which contributed to the characteristic scent of Surinam cherry, as reported by Melo et al. (2007). According to the Brazilian Pharmacopeia (ANVISA, 2020), curzerene is one the main Surinam cherry essential oil components, which, in this study, co-eluted with viridiflorene under the chromatographic conditions.

In Eugenia uniflora, the curzerene levels may be associated with the genetic diversity and wide geographic distribution. Costa et al. (2010) correlated the differences in essential oil composition of Surinam cherry leaves with the fruit color and identified three chemotypes with broad variation in the curzerene levels. According to the geographic location of Eugenia uniflora, curzerene levels of 19.7\% (Ogunwande et al., 2015), 22.4\% (Santos et al., 2015) and 47.3\% (Rodrigues et al., 2013) have been found in the essential oil of its leaves.

The results (Tab. 2) demonstrated that drying leaves at $45^{\circ} \mathrm{C}$ increased the monoterpene and sesquiterpene compounds in the Surinam cherry essential oil. A total of $67 \%$ of the identified compounds had an increase in the concentrations, with an increase of $11.83 \%$ in sesquiterpenes. Similarly, Corrêa et al. (2006) dried different medicinal and aromatic plants and concluded that the ideal drying temperature was determined by the volatile properties of the essential oil of the plant material.

Changes in the essential oil composition of Surinam cherry were also reported by Sellami et al. (2011) in results from drying and temperature conditions and the consequent oxidative process and chemical rearrangements. In the present study, the decrease and/ 
or increase of certain compounds between different drying temperatures (ambient and $45^{\circ} \mathrm{C}$ ) was related to volatilization ratio and/or chemical changes.

\section{Storage experiment}

\section{Essential oil yield}

The results showed that the essential oil yield was not significantly affected by the material type in the storage packages for the Eugenia uniflora leaves. On the other hand, there was a significant effect from the storage period on the essential oil yield of the dried Surinam cherry leaves (Tab. 3 and Fig. 1). The reduction in the essential oil yield was $32 \%$ after 60 d of storage, $41 \%$ after $120 \mathrm{~d}$ and $76 \%$ after $180 \mathrm{~d}$, as compared to the yield of fresh leaves (Tab. 3).

\section{Table 3. Relationship between average essential oil yield from dried Surinam cherry leaves during storage and from fresh (53.0\% moisture) and dried (11.0\% moisture) leaves without storage.}

\begin{tabular}{|c|c|c|}
\hline $\begin{array}{c}\text { Storage } \\
\text { (days) }\end{array}$ & $\begin{array}{c}\text { Relationship between } \\
\text { EO yield of fresh and } \\
\text { dried stored leaves }\end{array}$ & $\begin{array}{c}\text { Relationship between E0 } \\
\text { yield of 11.0\% moisture dried } \\
\text { leaves and stored dried leaves }\end{array}$ \\
\hline 0 & $1.0 \mathrm{a}$ & - \\
\hline 60 & $0.7 \mathrm{~b}$ & $0.6 \mathrm{a}$ \\
\hline 120 & $0.6 \mathrm{~b}$ & $0.5 \mathrm{a}$ \\
\hline 180 & $0.2 \mathrm{c}$ & $0.2 \mathrm{~b}$ \\
\hline CV (\%) & 23.8 & 31.6 \\
\hline
\end{tabular}

CV $(\%)=$ coefficient of variation; EO = essential oil. Means with the same lowercase letters in columns are not significantly different according to Tukey's test $(P<0.05)$.

A reduction in essential oil yield was also observed by other authors, which agree with the data in this study, comparing the effect of storage time of the plant material. Verma et al. (2011) found a reduction of up to $59 \%$ in the yield of essential oil extracted from Rosmarinus officinalis after $270 \mathrm{~d}$. According to Dušková et al. (2016), the increase in the storage period of Lavandula angustifolia flowers also decreased the essential oil yield when compared to flowers before storage. The reduction in essential oil yield during storage of plant material could be related to the high volatility of the essential oil components (Zuzarte and Salgueiro, 2015), which have an intrinsic characteristic. The loss in essential oil yield during storage could also be a result of the quality of the plant material. Drying plant material affects the integrity of the structures where the essential oils of Eugenia uniflora leaves are stored because it increases the volatilization of the essential oil components.

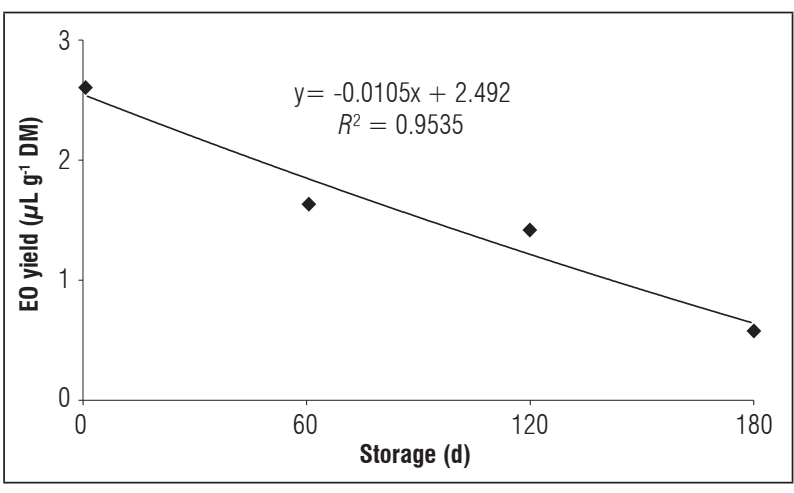

Figure 1. Essential oil (EO) yield of dried Surinam cherry leaves $(\mathbf{1 1 . 0 \%}$ moisture) during storage. Storage conditions: relative humidity $59.0-72.0 \%$, temperature $19-29^{\circ} \mathrm{C} ; \mathrm{DM}=$ dried mass.

\section{CONCLUSION}

Drying the Surinam cherry (Eugenia uniflora) leaves increased the essential oil yield after 24 and $48 \mathrm{~h}$ at $45^{\circ} \mathrm{C}$ and at ambient temperature. The levels of monoterpenes and sesquiterpenes also increased when the leaves were dried at $45^{\circ} \mathrm{C}$. The major compounds in the essential oil of the evaluated genetic material were curzerene and viridiflorene, which coeluted under the chromatographic conditions used in this study. The essential oil yield of the Surinam cherry leaves was not influenced by the packaging type during storage. However, storage reduced the essential oil yield of the dried Eugenia uniflora leaves.

\section{ACKNOWLEDGMENTS}

This research was supported by funding from the Agronomy Graduate Program of the University of Parana. The authors are grateful for the funding provided by CAPES - Brazilian Agency Foundation for Research, Brazil - who sponsored the senior author's graduate studies.

Conflict of interests: The manuscript was prepared and reviewed with the participation of the authors, who declare that there exists no conflict of interest that puts at risk the validity of the presented results. 


\section{BIBLIOGRAPHIC REFERENCES}

Abdelmageed, A.H.A., O.Z. Faridah, A. Nur Amalina, and M. Yaacob. 2011. The influence of organ and post-harvest drying period on yield and chemical composition of the essential oils of Etlingera elatior (Zingiberaceae). J. Med. Plants Res. 5(15), 3432-3439.

Adams, R.P. 2017. Identification of essential oil components by gas chromatography/ mass spectrometry. $4^{\text {th }}$ ed. Allured Publishing Corporation, Carol Stream, IL.

Amaral, W., C. Deschamps, L.A. Biasi, H.R. Bizzo, M.P. Machado, and L.E. Silva. 2018b. Yield and chemical composition of the essential oil of species of the Asteraceae family from Atlantic Forest, South of Brazil. J. Essent. Oil Res. 30(4), 278-284. Doi: 10.1080/10412905.2018.1434092

Amaral, W., C. Deschamps, L.E. Silva, H.R. Bizzo, M.A.S. Pinto, and L.A. Biasi. 2019. Essential oil yield and composition of native species of the Myrtaceae family from "Campos Gerais" of the Atlantic Forest in Parana State. Ciênc. Nat. 41, e45. Doi: 10.5902/2179460X40405

Amorim, A.C.L., C.K.F. Lima, A.M.C. Howell, A.L.P. Miranda, and C.M. Rezende. 2009. Antinociceptive and hypothermic evaluation of the leaf essential oil and isolated terpenoids from Eugenia uniflora L. (Brazilian Pitanga). Phytomedicine 16, 923-928. Doi: 10.1016/j. phymed.2009.03.009

ANVISA, Agência Nacional de Vigilância Sanitária of Brazil. 2019. Farmacopéia brasileira. Vol. 2. - Monografia: Plantas Medicinais. 6a ed. Brasilia, DF. In: http://portal.anvisa.gov.br/farmacopeia-brasileira; consulted: June, 2020.

Argyropoulos, D. and J. Müller. 2014. Changes of essential oil content and composition during convective drying of lemon balm (Melissa officinalis L.). Ind. Crops Prod. 52, 118-124. Doi: 10.1016/j.indcrop.2013.10.020

Costa, D.P., E.G. Alves-Filho, L.M.A. Silva, S.C. Santos, X.S. Passos, M.R.R. Silva, J.C. Seraphin, and P.H. Ferri. 2010. Influence of fruit biotypes on the chemical composition and antifungal activity of the essential oils of Eugenia uniflora leaves. J. Braz. Chem. Soc. 21(5), 851858. Doi: 10.1590/S0103-50532010000500012

Costa, D.P., S.C. Santos, J.C. Seraphin, and P.H. Ferri. 2009. Seasonal variability of essential oils of Eugenia uniflora leaves. J. Braz. Chem. Soc. 20(7), 1287-1293. Doi: 10.1590/S0103-50532009000700013

Corrêa Jr., C., M.C. Scheffer, and L.C. Ming. 2006. Cultivo agroecológico de plantas medicinais, aromáticas e condimentares. Ministério do Desenvolvimento Agrário, Brasilia, DF. pp. 58-65.

Dušková, E., K. Dušek, P. Indrák, and K. Smékalová. 2016. Postharvest changes in essential oil content and quality of lavender flowers. Ind. Crops Prod. 79, 225231. Doi: 10.1016/j.indcrop.2015.11.007

Fiuza, T.S., M.H. Rezende, S.M.T. Sabóia, M.T. Bara, L.M.F. Tresvenzol, and J.R. Paula. 2008. Caracterização farmacognóstica das folhas de Eugenia uniflora L. (Myrtaceae). Rev. Eletronica. Farm. 5(2), 21-31. Doi: 10.5216/ ref.v5i2.5148

Gallucci, S., A. Placeres-Neto, C. Porto, D. Barnizan, I. Costa, K. Marques, P. Benevides, and R. Figueiredo. 2010. Essential oil of Eugenia uniflora L.: an industrial perfumery approach. J. Essent. Oil Res. 22, 176-179. Doi: 10.1080/10412905.2010.9700296

Hannaa, M., Y.I. Sallam, A.S. El-Leithy, and S.E. Aly. 2012. Lemongrass (Cymbopogon citratus) essential oil as affected by drying methods. Ann. Agric. Sci. 57(2), 113-116. Doi: 10.1016/j.aoas.2012.08.004

Harbourne, N., E. Marete, J.C. Jacquier, and D. O'Riordan. 2009. Effect of drying methods on the phenolic constituents of meadowsweet (Filipendula ulmaria) and willow (Salix alba). J. Food Sci. Technol. 42, 1468-1473. Doi: 10.1016/j.lwt.2009.05.005

Lisboa, C.F., E.C. Melo, and S.M.L. Donzeles. 2018. Influence of storage conditions on quality attributes of medicinal plants. Biomed. J. Sci. Tech. Res. 4(4), 4093-4095. Doi: 10.26717/BJSTR.2018.04.001097

Lorenzi, H. and F.J.A. Matos. 2008. Plantas medicinais no Brasil: nativas e exóticas. $2^{\text {nd }}$ ed. Plantarum, Nova Odessa, Brazil.

Melo, R.M., V.F.S. Corrêa, A.C.L. Amorim, A.L.P. Miranda, and C.M. Rezende. 2007. Identification of impact aroma compounds in Eugenia uniflora L. (Brazilian Pitanga) leaf oil. J. Braz. Chem. Soc. 18(1), 179-183. Doi: 10.1590/S0103-50532007000100020

Ogunwande, I.A., N.O. Olawore, O. Ekundayo, T.M. Walker, J.M. Schmidt, and W.N. Setzer. 2015. Studies on the essential oils composition, antibacterial and cytotoxicity of Eugenia uniflora L. Int. J. Aromather. 15, 147-152. Doi: 10.1016/j.ijat.2005.07.004

Pirbalouti, A.G., M. Oraine, M. Pouriamehr, and S.E. Babadi. 2013. Effects of drying methods on qualitative and quantitative properties of the essential oil of Bakhtiari savory (Satureja bachtiarica Bunge.). Ind. Crops Prod. 46, 324-327. Doi: 10.1016/j.indcrop.2013.02.014

Pripdeevech, P. and E. Chukeatirote. 2010. Chemical compositions, antifungal and antioxidant activities of essential oil and various extracts of Melodorum fruticosum L. flowers. Food Chem. Toxicol. 48, 2754-2758. Doi: 10.1016/j.fct.2010.07.002

Rahimmalek, M. and S.A.H. Goli. 2013. Evaluation of six drying treatments with respect to essential oil yield, composition and color characteristics of Thymys daenensis subsp. daenensis. Celak leaves. Ind. Crops Prod. 42, 613-619. Doi: 10.1016/j.indcrop.2012.06.012 
Rocha, R.P., E.C. Elo, and L.L. Radünz. 2011. Influence of drying process on the quality of medicinal plants: a review. J. Med. Plants Res. 5(33), 7076-7084. Doi: 10.5897/JMPRX11.001

Rodrigues, K.A.F., L.V. Amorim, J.M.G. Oliveira, C.N. Dias, D.F.C. Moraes, E.H.A. Andrade, J.G.S. Maia, S.M.P. Carneiro, and F.A.A. Carvalho. 2013. Eugenia uniflora L. essential oil as a potential anti-Leishmania agent: effects on Leishmania amazonensis and possible mechanisms of action. Evid. Based Complement. Alternat. Med. 2013(Spe. Iss.), 279726. Doi: $10.1155 / 2013 / 279726$

Santos, F.R., R. Braz-Filho, and R.N. Castro. 2015. Influência da idade das folhas de Eugenia uniflora L. na composição química do óleo essencial. Quím. Nova 38(6), 762-768. Doi: 10.5935/0100-4042.20150072

Santos, J.F.S., J.E. Rocha, C.F. Bezerra, M.K.N. Silva, Y.M.L.S. Matos, T.S. Freitas, A.T.L. Santos, R.P. Cruz, A.J.T. Machado, T.H.S. Rodrigues, E.S. Britos, D.L. Sales, W.O. Almeida, J.G.M. Costa, H.D.M. Coutinho, and M.F.B. Morais-Braga. 2018. Chemical composition, antifungal activity and potential anti-virulence evaluation of the Eugenia uniflora essential oil against Candida spp. Food Chem. 261, 233-239. Doi: 10.1016/j. foodchem.2018.04.015

Sározi, Sz., L. Sipos, Z. Kókai, Zs. Plihár, B. Szilvássy, and I. Novák. 2013. Effect of different drying techniques on the aroma profile of Thymus vulgaris analyzed by GCMS and sensory profile methods. Ind. Crops Prod. 46, 210-216. Doi: 10.1016/j.indcrop.2013.01.028

Sellami, I.H., W.A. Wannes, I. Bettaied, S. Berrima, T. Chahed, B. Marzouk, and F. Lima. 2011. Qualitative and quantitative changes in the essential oil of Laurus nobilis L. leaves as affected by different drying methods. Food Chem. 126, 691-697. Doi: 10.1016/j. foodchem.2010.11.022

Shahhoseini, R., A. Estaji, N. Hosseini, M. Ghorbanpour, and R. Omidbaigi. 2013. The effect of different drying methods on the content and chemical composition of essential oil of lemon verbena (Lippia citriodora). J. Essent. Oil Bear. P1. 16(4), 474-481. Doi: 10.1080/0972060X.2013.813270

Silva, V.P., C.C.F. Alves, M.L.D. Miranda, L.C. Bretanha, M.P. Balleste, G.A. Micke, E.V. Silveira, C.H.G.
Martins, M.A.L. Ambrosio, T.S. Silva, D.C. Tavares, L.G. Magalhães, F.G. Silva, and M.B. Egea. 2018. Chemical composition and in vitro leischmanicidal, antibacterial and cytotoxic activities of essential oils of the Myrtaceae family occurring in the Cerrado biome. Ind. Crops Prod. 123, 638-645. Doi: 10.1016/j. indcrop.2018.07.033

Silva, F.A.Z. and C.A.V. Azevedo. 2016. The assistat software v. 7.7 and its use in the analysis of experimental data. Afr. J. Agric. Res. 11(39), 3733-3740. Doi: 10.5897/AJAR2016.11522

Stefanello, M.E.A., A.C.R.F. Pascoal, and M.J. Salvador. 2011. Essential oils from Neotropical Myrtaceae: chemical diversity and biological properties. Chem. Biodivers. 8, 73-94. Doi: 10.1002/cbdv.201000098

Van Den Dool, H. and P.D. Kratz. 1963. A generalisation of the retention index system including linear temperature programmed gas-liquid chromatography. J. Chromatogr. 11, 463-471.

Venditti, A., A. Bianco, C. Frezza, and F. Conti. 2015. Essential oil composition, polar compounds, glandular trichomes and biological activity of Hyssopus officinalis subsp. aristatus (Godr.) Nyman from central Italy. Ind. Crops Prod. 77, 353-363. Doi: 10.1016/j. indcrop.2015.09.002

Verma, R.K., L. Rahman, S. Mishra, R.K. Verma, A. Chauhan, and A. Singh. 2011. Changes in essential oil content and composition of leaf and leaf powder of Rosmarinus officinalis cv. CIM-Hariyali during storage. Maejo Int. J. Sci. Technol. 5(2), 181-190.

Victoria, F.N., E.J. Lenardão, L. Savegnago, G. Perin, R.G. Jacob, D. Alves, W.P. Silva, A.S. Motta, and P.S. Nascente. 2012. Essential oil of the leaves of Eugenia uniflora L.: antioxidant and antimicrobial properties. Food Chem. Toxicol. 50, 2668-2674. Doi: 10.1016/j.fct.2012.05.002

Voung, Q.V., N. Zammit, B.R. Munro, S. Murchie, M.C. Bowyer, and C.J. Scarlett. 2015. Effect of drying conditions on physicochemical and antioxidant properties of Vitex agnus-castus leaves. J. Food Process. Pres. 39, 2562-2571. Doi: 10.1111/jfpp.12506

Zuzarte, M. and L. Salgueiro. 2015. Essential oils chemistry. pp. 19-61. In: Sousa, D.P. (ed.). Bioactive essential oils and cancer. Springer International Publishing, Cham, Switzerland. Doi: 10.1007/978-3-319-19144-7 